\title{
Remembering, History, and Identity: The Sculpted Life of Benjamin Franklin
}

Mert Deniz

\section{(2) OpenEdition}

\section{Journals}

Electronic version

URL: https://journals.openedition.org/ejas/14721

DOI: 10.4000/ejas. 14721

ISSN: 1991-9336

Publisher

European Association for American Studies

\section{Electronic reference}

Mert Deniz, "Remembering, History, and Identity: The Sculpted Life of Benjamin Franklin", European journal of American studies [Online], 14-2 | 2019, Online since 09 July 2019, connection on 08 July 2021. URL: http://journals.openedition.org/ejas/14721 ; DOI: https://doi.org/10.4000/ejas. 14721

This text was automatically generated on 8 July 2021

Creative Commons License 


\title{
Remembering, History, and Identity: The Sculpted Life of Benjamin Franklin
}

\author{
Mert Deniz
}

\section{Introduction}

1 Philadelphia was an important city in the life story of Benjamin Franklin, as well as in American art history. It was the first city where sculpture was introduced to America as a form of high-art with Franklin's bust by Jean-Jacques Caffiéri (Craven 4-7). It was the town where Franklin escaped to actualize himself and build his own life as a Self-Made Man. His representations in the city consist of various statues, which were created by different artists at different times, spanning from the late nineteenth to the twentyfirst century. They provide quite diverse portraits of Franklin rather than following a stereotypical model. They focus on different moments of Franklin's life and foreground his myriad roles as a businessman, statesman, scientist, diplomat, and so forth.

2 Franklin was a man of the Enlightenment, who was drawn to multiple subjects, from civil administration, to music composition, and to scientific experiments. He is generally considered a Self-Made Man, yet there is more than that underlying this superficial definition. He is also referred to as the "First American" who developed an American identity distinguishable from that of a citizen of a British colony. These details turned him into a role model and a polychromatic sociological figure. As a man foregrounded as the prototype of the national identity, Franklin had to meet the expectations of an entire nation as a role model, so his multiple identities and relatively undocumented background as a Self-Made Man metaphorically created a canvas to be redefined with the ideals of his people. As the result, the cult of Franklin was born from his own works as much as from the stories of his peers. John Adams was one of the first observers of this myth of Franklin, which began to be woven by the 
Pennsylvanian's admirers as early as 1790, just a year after the end of the Revolutionary War (Mulford 415).

3 The American nation recreated Franklin, as all nations do for their public figures, as a man of science to provide a role model for a country that exalts rationalism and secularism; as a diplomat for the country that declares itself as a city upon a hill for the rest of the world; as an engineer and craftsman for the country that praises industry and production; as an eighteenth-century revolutionary for the country that is proud of its independence and sovereignty; and finally as a Self-Made Man for the country that believes it has an exceptional identity from its European origins and writes its own destiny. As this paper will argue, the statues, commemorating Franklin in the City of Philadelphia, were made by the people who were exposed to these ideas, which mutually shaped their own views about Franklin and America. Moreover, these statues, as artifacts of history, represent social values, traditions, ideals, and history of America, because they are the reflections of the very same society, which produced them. Eventually, America remade Franklin as a Socially-Made Man, and this Franklin - or Franklins, as it were-(re)construct and reinforce narratives of American memory and its national identity.

\section{Memory and (Re)membering}

In the introduction to The Archaeology of Knowledge, Foucault says that "the document is not the fortunate tool of a history that is primarily and fundamentally memory; history is one way in which a society recognizes and develops a mass of documentation with which it is inextricably linked" (5). Accordingly, what is called history is actually the documentation of memory, and like written texts statues can also be read, namely as visual texts and artifacts of history. Furthermore, history is primarily made of memory which is socially and individually constructed. Hence, the nature of memory is the first one of the decisive components of history, the other two elements of which are remembering and narration.

Nonetheless, memory is not a monolithic structure. Instead, it is a cognitive model which has more than one aspect as argued by John Sutton, Celia B. Harris, and Amanda J. Barnier (211). The "declarative memory system," or the conscious side of memory, has certain functions according to this model. Developed by Richard Atkinson and Richard Shiffren, this model takes remembering as a discursive and subjective process. The human mind creates the subjective narratives, or the "truth" about the past, which is limited by memory's consciousness. Even if an individual can recall his or her memories "consciously," it does not mean that s/he is aware of the reflections of his or her personal ideology, feelings, and perspective in the narration of memories. This includes history writing as an artifact of memory.

6 Atkinson and Shiffren assign three tasks to memory, which are "encoding," "storage" and "retrieval" (211-2). Within the scope of these tasks, it can be argued that human consciousness has a limited nature as an individual encodes data from his or her own perspective, together with ideas, emotions, and other related factors, which comprise one's subjectivities. The individual can retrieve this data at a future date along with these subjectivities, and this defines the act of remembering. On this matter, Laura Mattoon D'Amore argues that “[r]ather than simply passing along knowledge of history, commemoration passes on the knowledge of our present interpretation of the 
past... commemorative practices are revised and rebuilt based on the spirit of time in which it is re/created" (Meriwether and D'Amore xvi).

7 Sutton, Harris, and Barnier also posit that "memory is largely constructed" and that it always involves "personal motivations, social motivations, and situational demands" (213). Thus, the storage of memory is not a deposit of actual or accurate images of the past or "truth," but rather a space for the retrospective collection of data, subjectively interpreted and perceived from a certain perspective at the moment of collection, namely encoding. Consequently, memory, history's primary component, according to Foucault, is highly subjective, and what an individual does, in the course of remembering, is actually collect pieces of memories together with subjectivities from his or her own repository and to create a patchwork or pastiche, thereby making remembering a discursive activity.

If memory is a fragmented cluster of data, then how can an individual remember it in a cohesive manner that makes sense at the present moment? The answer is that human brain comprehends details in the sense of causality (Martin and Deutscher 164). It reflects in what is named to be the "language of memory," which functions in a "continuous causal process" (Martin and Deutscher 175). The brain orders memories according to the association of time sequence or causality. Chronology plays an important role in this process as it is a quintessential means to observe and express the relation of causality between two or more fragments of memory.

9 Furthermore, these theories on the nature of memory demonstrate that remembering is a narrative activity, even before it is interpreted into a historical artifact like a history book, a statue of a public figure or anything else that is supposed to provide a resemblance of a historical subject. Examining the nature of memory and remembering with regard to Freud's clinical studies, Roger Kennedy argues that the distinction between past and history becomes real at the point where an inquisition of memory is performed, which we call remembering (Kennedy 181). Therefore, if we define memory as a pile of retrospective data, gathered whether from "direct" or "indirect" sources through experiencing or learning, respectively, remembering can be metaphorically defined as mining pieces of data (Martin and Deutscher 162).

"The raw material" that one obtains as the result of this process is nothing less than the recollection of his fragmented memories with attached emotions and ideas, namely subjectivities (Kennedy 183). Additionally, this process is not indifferent to its environment, so it is a reactive process rather than a static one as the fragments of memory are "rearranged" according to the contemporary events taking place around the subject (Kennedy 185). Briefly, remembering brings out memories together with connected emotions and ideas, and it happens in correspondence with the given environment where they are retrieved, and in a manner that makes sense at the present moment by being mainly chronological and causal. 


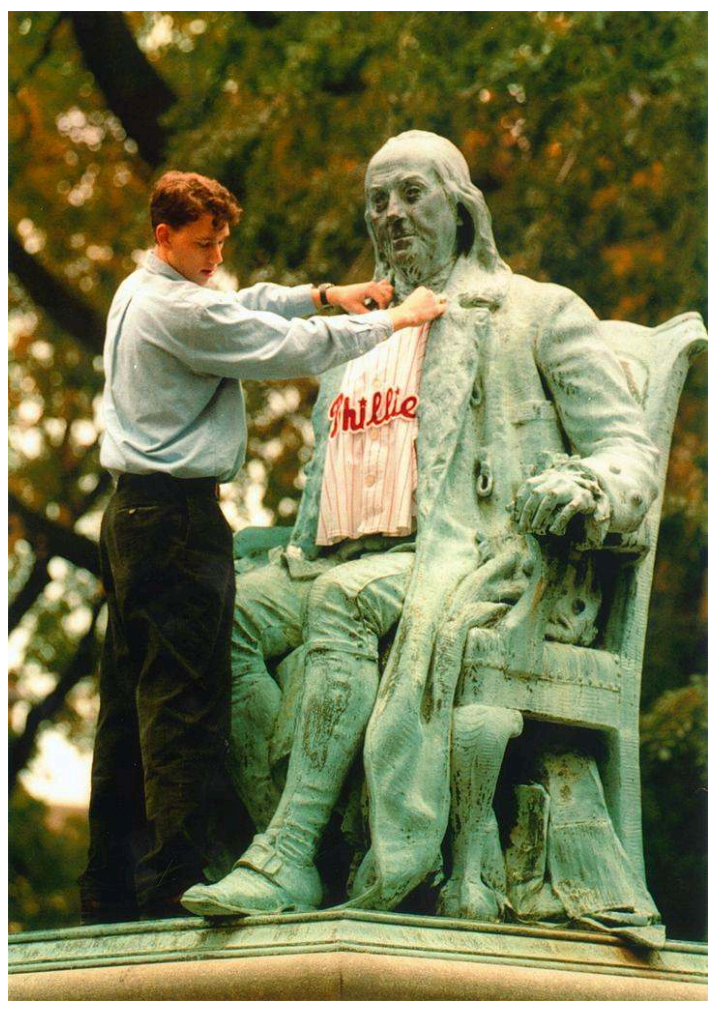

Fig. 1. Ben the Phan. 1993. University of Pennsylvania, Pennsylvania. Artstor Library.

After all, (re)membering is a process of (dis)membering. The artifacts of history are "decoded" as much as they are encoded from direct or indirect sources of memory. This is directly related to the retrieval process of the encoded fragments from the storage of memory as people reconstruct these dismembered raw materials in a manner that is meaningful in their present moment. Consequently, this process provides a constructed portrayal of the past, merging these fragments of memory with the subjectivities of the people. With these two composite elements of memory, an artifact of history comes into being and is given meaning as a narration.

13 Narration through statues is created by an individual on the basis of his or her memories, covering direct and indirect sources of memory along with the subjectivities, and once it is complete, it conveys a resemblance of historical "truth" to its audience. The audience also encodes such narrations together with their own subjectivities and retrieves all of these together at a future moment.

As remembering creates the historical resemblances of "truth," one needs to develop a belief of "reality" in the narrated memories regardless of one's position whether as a narrator or an addressee (Martin and Deutscher 167). In this matter, remembering is not only a narrative construct, but also a self-deceiving act. In other words, the difference between reality and imagination, or "falsity" to be more specific, is the intensity of the individual's belief in the "truth" of memories (Martin and Deutscher 187-8). In this matter, Franklin's statues are not the mere representations of the retrospective "truth," they are actually the models, made by the people, for what people expect to see in their role model (Fig. 1.).

15 At this point, narration plays its own part as the means of conveying the "truth" as well as convincing the audience of the truthfulness of the artifact to the actual images of the past by creating a kind of authenticity effect. Consequently, it is meaningless to 
attempt to establish any differences between the outcomes of direct and indirect origins of memory fragments. They are both constructed and equally important as historical sources, if they are taken into account as the narrative reflections of the social realities of a given period of time.

Hence, the nature of subjectivities inside an individual's memory storage is even more complicated than it is commonly is thought to be. It contains the fragmented historical data as it also becomes the realm wherein the subjectivities of the narrators of historical artifacts merge with the subjectivities of the individual. This phenomenon provides the formation of individual and collective identities based on the narration of an artifact of history as well as the perceived narration, both of which blend inside an individual's memory.

17 As well as being made of memory and produced by remembering, historical narratives themselves are also sources of memory as they provide data to be recollected either by their narrators or other individuals, once they are made public. An exemplary case for this situation is one of the first statues of Benjamin Franklin. This statue was sculpted by Italian artist Francesco Lazzarini in 1789 and is located at the Library Company of Philadelphia today (Fig. 2.) This statue was shaped not only by Lazzarini's Italian background, but also by the Founding Fathers' well-known romanticism of the Republican Era of Rome with its eminent leaders like Cicero, Cato, Tacitus, Varro, Cincinnatus, and so forth (Richard 9-51). Therefore, it is a good example of how the perception of the narrator, Lazzarini, and self-representation of the audience, the Founders and Americans, and even the artistic subject, Benjamin, merged into a statue that embodies a certain narrative.

David Hackett Fisher defines Franklin's image as "a leader of the Revolution" by referring to French philosopher Turgot's epigram for Franklin, which is as such: "he seized the lightning from the heavens, and the scepter from tyrants" (Fischer 186). In the words of Turgot, Franklin's two images, the Cartesian philosopher and the revolutionary leader, are unified to create a single image, the Man of Enlightenment, and this state of enlightenment came with its sociopolitical significance. 


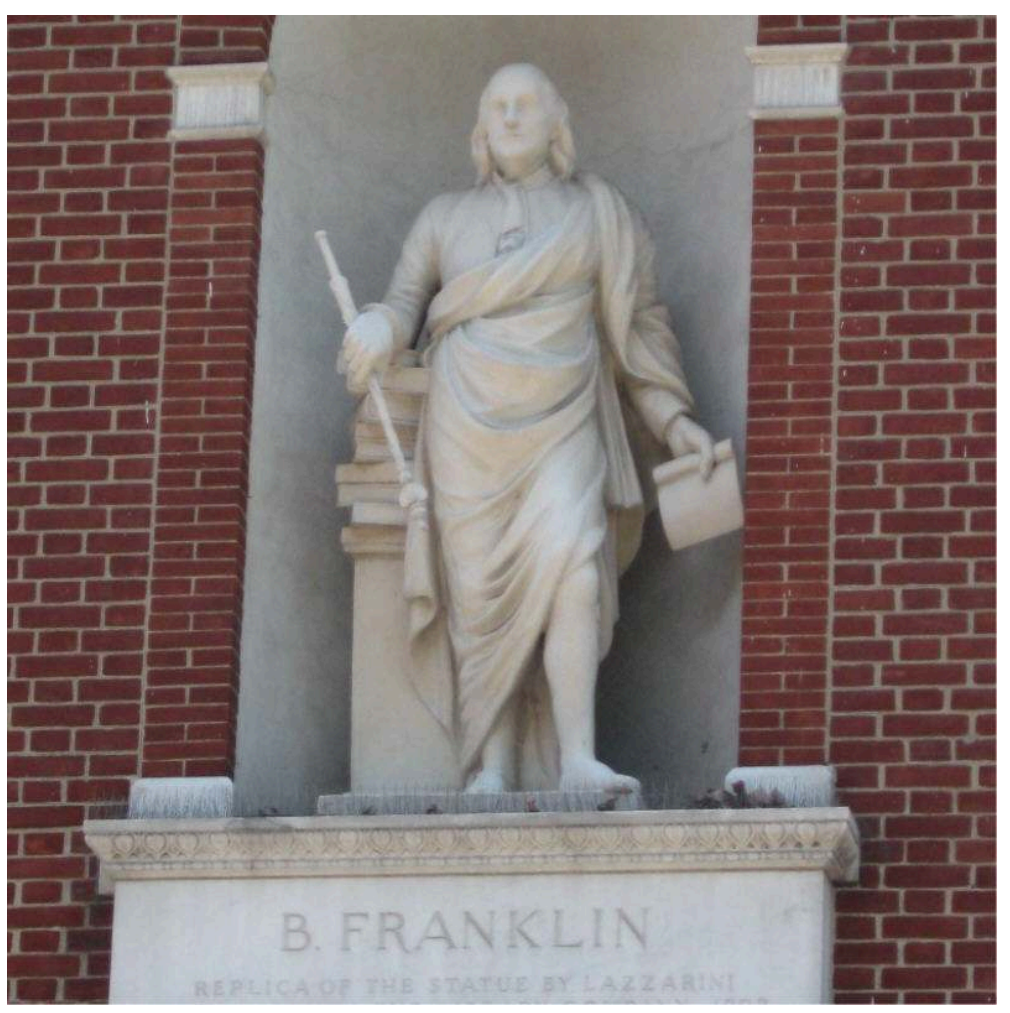

19 Fig. 2. Francesco Lazzarini. Benjamin Franklin. 1789. Photographed by Christopher William Purdom. Philadelphia Public Art.

Francesco Lazzarini's Benjamin Franklin was, thus, the embodiment of this Franklin, the Enlightened and Virtuous Republican. In this image, Franklin is depicted holding a scepter downwards, representing his act of seizing the scepter from tyrants in reference to Turgot's epigram. Furthermore, Franklin rests his scepter holding elbow onto a pile of books since he takes his power from Reason as a scientist and writer. Therefore, science and politics are assembled as two subjects in which Franklin served as a leader.

21 Lazzarini's Franklin, additionally, holds a piece of parchment, alluding to those which were used by Romans. One cannot help seeing the connection between his garments and this parchment's message as it represents the axioms of the Republican Rome, defined by Cicero as res populi, iuris concensus and utilitatis ommunion sociatus-which can be translated into English language as a government for the people, society based on law, and a nation with common values (Kaldellis 25). These axioms provided the fundamentals of the concept of the "Republic" for the Founders.

The love of the Founders of the United States for the ancient Republic of Rome clearly reflected on their representations as well as their utopia of ideal society and government. Among them, a common compliment was defining an appreciated person as "well educated in the Classic's" as James Madison did in one of his letters to indicate the intellectual profundity of a member of the community (Madison). Moreover, the Founders were not alone in this sense within the American society of the Revolutionary Era. Imitating the actions of the prominent Roman leaders was a sign of virtue as was stated by an unknown author in his complimentary statements to George Washington: "You Sir, like Cincinnatus have retired, with the applause of every Good Man" ("To Washington"). Hence, the marble model of Franklin in a toga symbolizes once again in a conscious manner his exaltation as a model Republican and a man of Virtue. Once 
again, the narrator's subjectivities and social dynamics of a historical society are blended in the model of a public figure, presenting a good example of an artifact of memory and collective identity for scholars.

Apparently, an artifact of history conveys a constructed narration, and also provides a set of data for its audience, who believe in learning the "truth" about the past from this artifact, while receiving the subjectivities of the artifact's narrator in the course of the encoding process. The contemporary audience of Lazzarini's statue sees Franklin as represented like one of the heroes of the Republican Rome and associated with the values of republicanism, patriotism, and civil-service. Memories of Franklin are now amalgamated with the social values of the past, and these values are, thereby, conveyed to the present in conformance with the ideas of the creator of this artifact, Lazzarini, and his contemporaries, American society of the late nineteenth century.

\section{Benjamin Franklin and Identity}

Maurice Halbwachs argues that societies can also reconstruct their memories in order to create a sense of unity among their members (Apfelbaum, 83-4). What is lying between the lines of Halbwachs' argument, quoted and analyzed by Erika Apfelbaum, is that identity is also remade by society, which stands for an agency in the narration of memories. To be more specific, the artifacts of history simply generate narrations of the past from fragmented memories, yet they also provide social models for the audience to construct their identities on the basis of such models at the present.

Society plays a crucial role in the process of an individual's developing his or her own identity as well as establishing his own memory storage. Without constructing a meaningful narrative of the past, none can develop a complete identity and give meaning to his or her present. Apfelbaum, again commencing from Halbswachs' approach to history and sociology, foregrounds the importance of society in the process of identity-making. She writes,

[I]nterpersonal proximity, in particular emotional proximity, is a necessary condition at the interpersonal level to make communication possible, to establish meaningful dialogue, one that helps subjects to process their experiences into living memory and facilities the storage and retrieval, rather than the repression and forgetting, of their memories. (Apfelbaum 88)

In this matter, Benjamin Franklin's statues are more than static reinterpretations of the past; instead, they are dynamic constructs which are remade in the minds of their audience in the course of their identity making. They get involved in a dialog with their audience, and the audience develops both collective and individual identities through this process.

The artifacts of history are not only the products of memories, but they are also the raw materials of new narrations. Identity making, at this point, is a form of individual narration, and people-the audience-reconstruct their own identities by internalizing these artifacts as their reference points for the past. This is how an individual develops identity within the dialog of external and internal subjectivities. This can be seen in all sources of history, as John Adams has already observed, Benjamin Franklin was one of the objects of this history-making process in America (Mulford 416-7). What one sees in the statues of Franklin is not the original source of these artifacts, but the remade 
models of this source, together with the memory fragments and subjectivities of the narrators, who are also members of the audience, themselves.

It is true that everything is historical or memorial as an individual takes over the meanings and identities of objects, public figures, and events regarding their historical background. As already discussed, human brain remembers on the basis of causality and creates meanings by decoding the fragments of past experiences, kept inside his or her memory storage. Recalled in the narrations, organized in a chronological order and the relationship of causality, narrations of history are created by individuals, and this "narrativity" becomes the crossroads of history, memory, primary sources, and secondary sources (Greene 100-2).

Therefore, what is argued here is that historical narrative is a concept that is much more comprehensive than the limited definitions of formal narratives, and it is a fundamental component of one's self-definition. However, every narrative needs a basis to be built upon. Such material must be flexible enough for the narrator to engrave his own depictions and adaptable enough for the audience to embrace it as a part of their identities. R. Trait McKenzie's Young Benjamin Franklin sets an example for the suitability of Franklin to be the mannequin of the artists who clad him in different identities.

Franklin's flexibility and adaptability as a foundation of various identity models has its roots in his own life story as a Self-Made Man from Boston and his unlimited ambition to realize himself in several paths of life. Walter Isaacson defines Benjamin Franklin's decision to move from his hometown Boston to Philadelphia with these words:

It was a tradition among American pioneers, when their communities became too confining, to strike out for the frontier. But Franklin was a different type of American rebel. The wilderness did not beckon. Instead, he was enticed by the new commercial centers, New York and Philadelphia, that offered the chance to become a self-made success (Isaacson 35).

Therefore, the first model of Franklin occurred in Philadelphia was the model of the Self-Made Man, who left his hometown in the pursuit of success in life. Hence, R. Tait McKenzie's sculpture of Young Benjamin Franklin, erected in 1914, is one which initiates the story of Franklin (McKenzie).

It was a project of a group of students from University of Pennsylvania, who thought that there was no monument on the campus to indicate that the school's founder was Benjamin Franklin ("Young Franklin Statue"). McKenzie was chosen because he was not only an acknowledged sculptor, but he was also the head of the physical studies department. The sculptor and the representatives of the Class of 1904 agreed on "the image of a young man with very little personal property, no job, and certainly no fame... to inspire new Penn students" ("Young Franklin Statue"), so Franklin was depicted as a 17-year-old young man, as in 1723 (Fig. 3). 


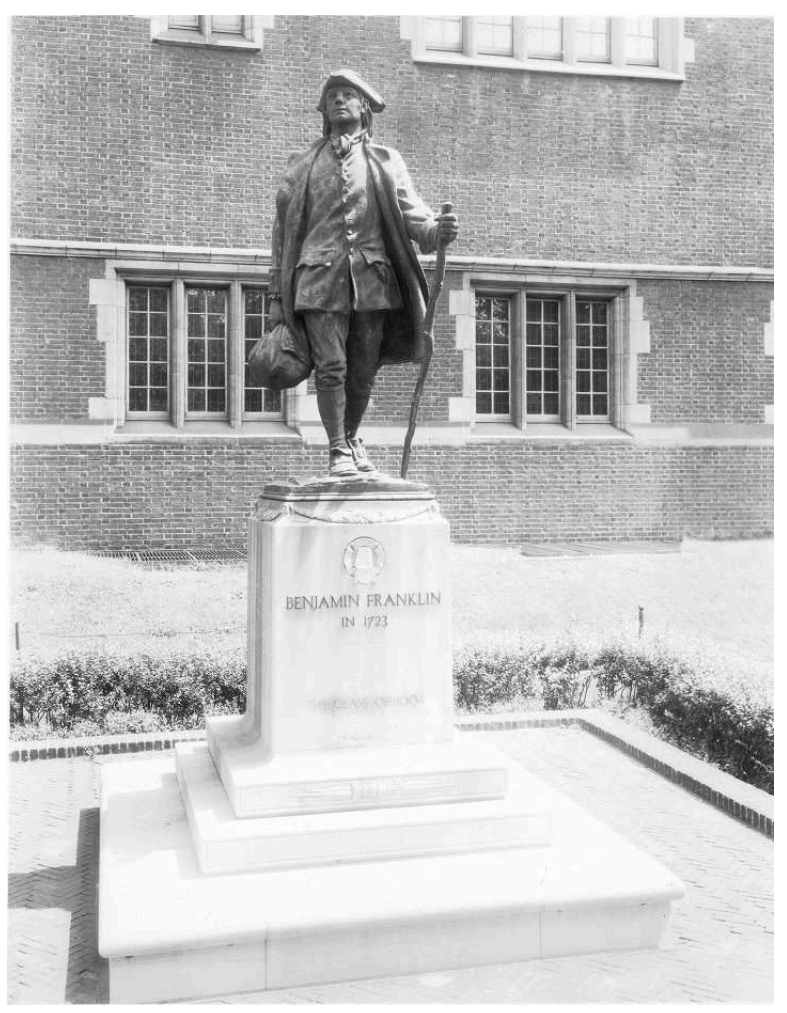

Fig. 3. R. Trait McKenzie. The Young Franklin. 1914. University of Pennsylvania, Pennsylvania. University Archives \& Records Center.

Therefore, Franklin in this model is the embodiment of Tabula Rasa. He holds a wooden stick in his hand to show that he was on a journey as he had a long-way ahead and a great potential, lying in his future. In terms of his clothing, he was not in a wretched situation, but he is not clad in anything luxurious, either. Apparently, leaving his hometown and arriving at Philadelphia was the first milestone of Franklin's journey from "rags to riches." Moreover, Franklin's modest depiction enhances another aspect of his representation. He stands for the "everyman" of the early American society as James M. Beck remarked in his speech for the unveiling of the statue on 16 June 1914:

Does not this Franklin with his staff in one hand and his meagre possessions in the other, with uplifted eyes, alert, vigorous carriage and smiling, resolute face, nobly symbolize the youth of America, as they end their apprenticeship, and bravely face on the threshold of manhood the rude challenge of the world? (Beck 5)

Obviously, the statue was appreciated for providing a visual artifact of mythological history in order to inspire the university students, a young and male-dominated group of society at that time. Hence, Franklin's representation here stood for the idealized roots of modern America in 1723, which was destined to go through a world-changing journey to actualize itself as an independent state.

Benjamin Franklin had become a semi-mythical figure for American society much before the end of the nineteenth century. By the early 1800s, there were already mythologies of Franklin, widely circulated around the country as a model of the ideal citizen, who was expected to be patriotic, pious, self-sufficient, and industrious, and as a proof of the achievability of the American Dream (Mulford 419-20). The ideal citizen had to reflect the newly independent Christian America and its success-oriented culture, causing the paradoxical existence of a half utilitarian, half materialist society. It was a perfect example for the reproduction of history in the hands of narrators, as 
discussed in the previous parts of this study, as well as how a public figure turns into an identity model for the audience of the artifacts of history.

Speaking of these specific artifacts, Carla Mulford says "[p]erhaps the best evidence that Franklin's had become a traditional figure by the end of the nineteenth century lies in the public orations delivered at the unveilings of various statues erected to honor him" (436). As it can be understood, these statues became the pulpits for the expression of the social values, role models, and public discourses that defined American society. For this reason, these statues, carrying all the features of such artifacts including the subjectivities of their creators, are to be studied as the conveyors of the values that American society had already begun developing before the date when these statues were erected.

Based on the aforementioned traditional values, the identity models, reflected on these artifacts, are, respectively, the models of the Self-Made Man, already discussed regarding R. Trait McKenzie's Young Benjamin Franklin, Heroic Artisan, Revolutionary, Printer-Journalist, Scientist, Diplomat, Virtuous Republican, also already discussed regarding Francesco Lazzarini's Benjamin Franklin, and finally as Founding Father. For this reason, the statues of Franklin are not given in a chronological order, regarding the dates when they were opened to the public, covering a gigantic span of time from 1789 to 2017 , but in a contextual order with regard to the dominant themes in the history of the United States.

The actual matter of concern in this study is that Franklin was not necessarily an ideal person for all of these models, which would require an inhuman energy to meet the exaggerated necessities of all of them. On the contrary, Franklin was a jack-of-alltrades, as remarked by Verner W. Crane "[w]hat has puzzled men most about Franklin is that he turned so often and so easily from one career to another" (Crane 205). However, Franklin provided a reachable model, which the narrators could reshape according to their discourses, rather than a colossal and almost dogmatic figure, which would be impossible to add or omit any details from its original. In this respect, he was suitable for becoming a social figure, recognized and appraised as a model citizen, and this turned him into an almost mythological figure in the hands of people like Mason Locke Weems, Robert Thomas, Amos Taylor and Silas Felton alongside with their many successors in this myth-making process. These people were criticized by John Adams and Henry Cabot Lodge as the former witnessed the beginning of this process and the latter faced the results it had reached by the end of the nineteenth century (Mulford 415-21 and 438). Nonetheless, whether they were to be criticized or not, what these narrators made is what is called "memory-making."

However, they were not necessarily false or, even more seriously, malign propagators, they were just human beings who were remembering Franklin in a certain way from their points of views and for the satisfaction of their audience, who expected to see Franklin in a certain way in accordance with their own social ideals. Descartes tried to define the differences between perspectives with the nature of light that reflects from objects and projects on the eyes of spectators, and in their eyes, visual imitations of these objects occur, and the difference between these imitations provide different perspectives about the object. This is how light turns into meaningful images before coming into being and everyone has their own perception of the reflecting object regarding where they stand (Descartes 60-4). 
Eventually, memory, just like light, is transformed into material in memory and the narrations of people without being limited only to their eyes. Historians, artists, family members, teachers, and basically every single member of the society are the narrators of memories as they all remember. They reshape memories in their reconstructions of the past, namely the act of remembering; meanwhile, they redefine their world according to what they remember. Hence the audience and the material become the objects of a narrative as artifacts of history and memory. This is how collective and individual memory occurs and works, and this is how people develop role models and identities for themselves. Therefore, Franklin's statues are just some of the examples of these artifacts of memory, and it is futile for the scholar to undertake a Sisyphean attempt to separate myth from "truth" like Henry Cabot Lodge did more than a century ago.

\section{Miscellaneous Franklins and American Identities}

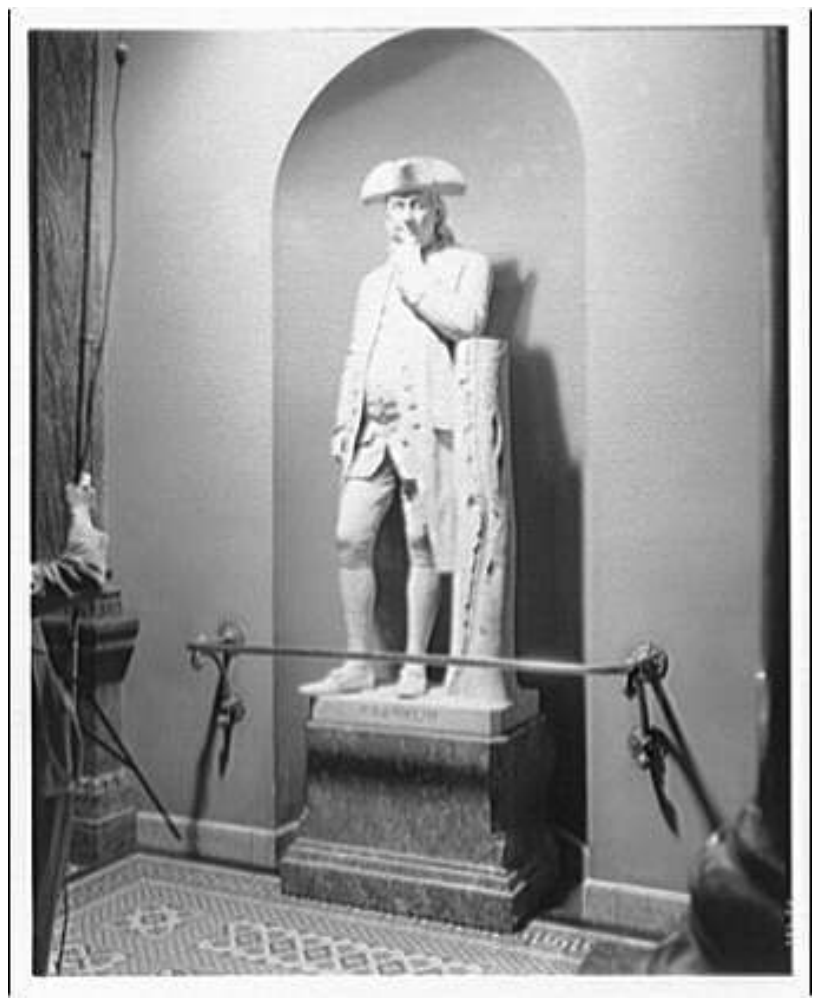

Fig. 4. Hiram Powers. Benjamin Franklin. 1862. Library of Congress Prints and Photographs Division, Washington, D.C. Library of Congress.

Another model of young Franklin is that of Hiram Powers. It is not located in the City of Philadelphia but at the Senate in Washington D.C.; however, it is strongly coherent with its counterparts in this study (Fig. 4). Powers was a witness to the Italian Independence War of 1848 and the French Revolution of 1848. These were two separate but related conflicts of Europe which broke out between Nationalist-Socialist political groups in these countries and the sovereign empires as the former sought national unity and independence from monarchs as new republics. Powers vocally stated his belief in the United States' position as a role model for these young nations of the Old World (Fryd 65). Additionally, Powers was a Unionist during the turbulent years of the American 
Civil War, and he advocated that the only way to prevent the sufferings and wars of the European separatist movements, which eventually led to the Great War, was to promote the traditional ideals of unity and republicanism of the Founding Fathers and the Revolutionary Era (Fryd 66). Hence, it was believed that the solution for the crises of these turbulent years lay in the elevation of the fundamental ideals present at the foundation of the United States.

By these reasons, Benjamin Franklin, the architect of the American unionism with his Albany Plan of Union during the French and Indian War of 1754, the symbol of American freedom and unity, was chosen together with a statue of Thomas Jefferson (Fryd 67). Powers remakes Franklin as a young individual who is leaning on a column, given the look of a tree trunk, in his sculpture, opened to the public in 1862, just a year after the Fort Sumter incident in the first year of the Civil War. Powers' statue was erected at the time when America was questioning its identity and meanings of freedom, equality, and union. This model of Franklin is represented in a thoughtful manner as one of the eminent strategists of American independence and the Revolutionary War by having been involved in the determination of the proper strategy that Americans had to follow even before the French and Indian War (Stourzh 33-65).

However, this model is not depicted with a grim-look, instead he gives the impression of a shrewd strategist, planning for his next move against the enemy. Reinforcing the active look of the statue, Franklin wears a long coat, resembling to the uniform of the Continental Army officers, with open buttons, and displays a casual stance with his legs. He is neither retreating nor paralyzed by fear at his position, but he is carefully observing and devising his next move. His garments and expression contribute to the masculine look of the model. Instead of being a desk-bound strategist, Franklin's clothes are those that one could wear for a field survey to examine whether his theories could be adopted on the battlefield. Therefore, the revolutionary Franklin was depicted to be as much of a soldier and a commander as he was an enlightened intellectual in the military sciences, as well. This is a common characteristic, attributed to the Founders of the United States, as they were the leaders of the country during the wartime as well as the patriarchs of the post-bellum nation-making period.

\section{1 The Craftsman}

The revolutions of the eighteenth century were the results of the dramatic changes in sociopolitical environment. Benjamin Franklin lived in a transitory era, going through a metamorphic stage from agriculturalism to steam-powered industrialism as Morgan states:

The fact that Franklin thought doing things better with nothing but hand power tells us something both about him and about his time. He liked doing things himself. He was continually designing experiments and constructing apparatus to carry them out, but mostly they were things he could do by himself or that he could get some craftsman to do his directions. He must have been very good with his hands, and the world he knew was a world in which nearly everything was done by hand. That world was changing, even in his own life time[.] (8)

Nevertheless, not every statue of Franklin portrayed him as a manual worker; instead, most of them represent him as an intellectual, patriarch, diplomat, et cetera. What changed before the 1980s was that the United States needed to reaffirm its masculinity before the last run of the Cold War, which was not known to be the last at that time, yet 
it was obvious that both the contenders were tired of a restless contest of almost thirty years in the past. In addition to the negative impacts of the long years of fluctuation between entente and détente, the economic recession of 1973-75, following the oil crisis of 1973, meant the end of the prosperous years after the Second World War, so America needed to remember the importance of industriousness and frugality, once again.

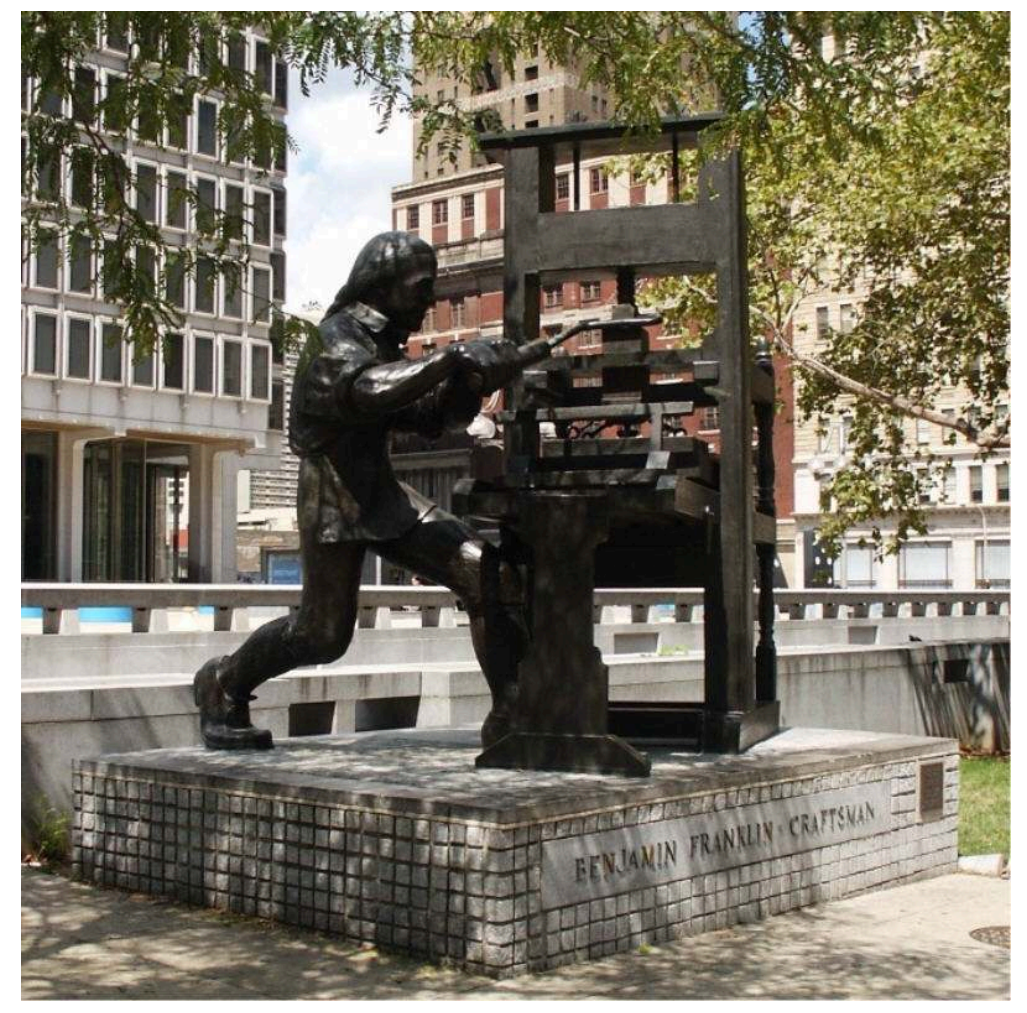

48 Fig. 5. Joseph Brown. Benjamin Franklin, Craftsman. 1981. Photographed by Christopher William Purdom. Philadelphia Public Art.

49 Benjamin Franklin, Craftsman is located near to the Masonic Temple of the Pennsylvania Freemasons, which commissioned Joseph Brown to create a model of Franklin in a manner that recalls his work as a printer and an artist ("Benjamin Franklin, Craftsman"). Eventually, the artist creates a craftsman Franklin in his statue, opened to the public in 1981 (Fig. 5). The statue shows a lean-bodied Franklin fixing the plates of a primitive printing press. The model has enormous feet along with hands holding a tool to adjust a highly complex machine for Franklin's era, the printing press. The slightly disproportional feet, hands, and strong arms of the model amplify the masculine appearance and physical strength that is required, and thus it establishes an analogy between manhood and industriousness.

50 The depiction of Franklin as an industrial craftsman corresponds to one of the early ideals of American manhood, named as "Heroic Artisan" by Michael Kimmel and defined as "independent, virtuous, and honest... stalwart and loyal... unafraid of hard work, proud of his craftsmanship and self-reliance" (Kimmel 13). Therefore, the Heroic Artisan was the father of the patriotic and industrious workers of America, and Franklin was, of course, a model for this identity, thanks to the stories about how hardworking he had been since his youth. Among the other qualities of Franklin, the embodiment of the masculine strength and the laborer's perseverance and resilience was what the American audience wanted to see in their favorite role model in these 
hard times. The Heroic Artisan had to be resurrected from his grave, lying where he had died in the middle of the automated factories. He needed to come up with his vigor, bravery, and resilience against pain-staking tasks of the industrial and military races of the Cold War years in order to teach his people the importance of austerity and frugality during economic crises.

\subsection{The Printer}

Benjamin Franklin's socially acknowledged characteristics were much more numerous. Being one of these features, even as early as his teenage years, Franklin impactfully used written media as a means of spreading his thoughts and ideas on many subjects by writing under various pseudonyms such as Silence Dogood, his first pen-name, Busy Body, Anthony Afterwit, Alice Addertongue and Benevolus as well as others, almost all of which were given metaphorical names and had an impact on the sociopolitical affairs of Franklin's era (Isaacson 186). George Lundeen's representation of Benjamin Franklin, opened to the public in 1987, foregrounds Franklin's identity as a publisher and public informer (Fig. 6).

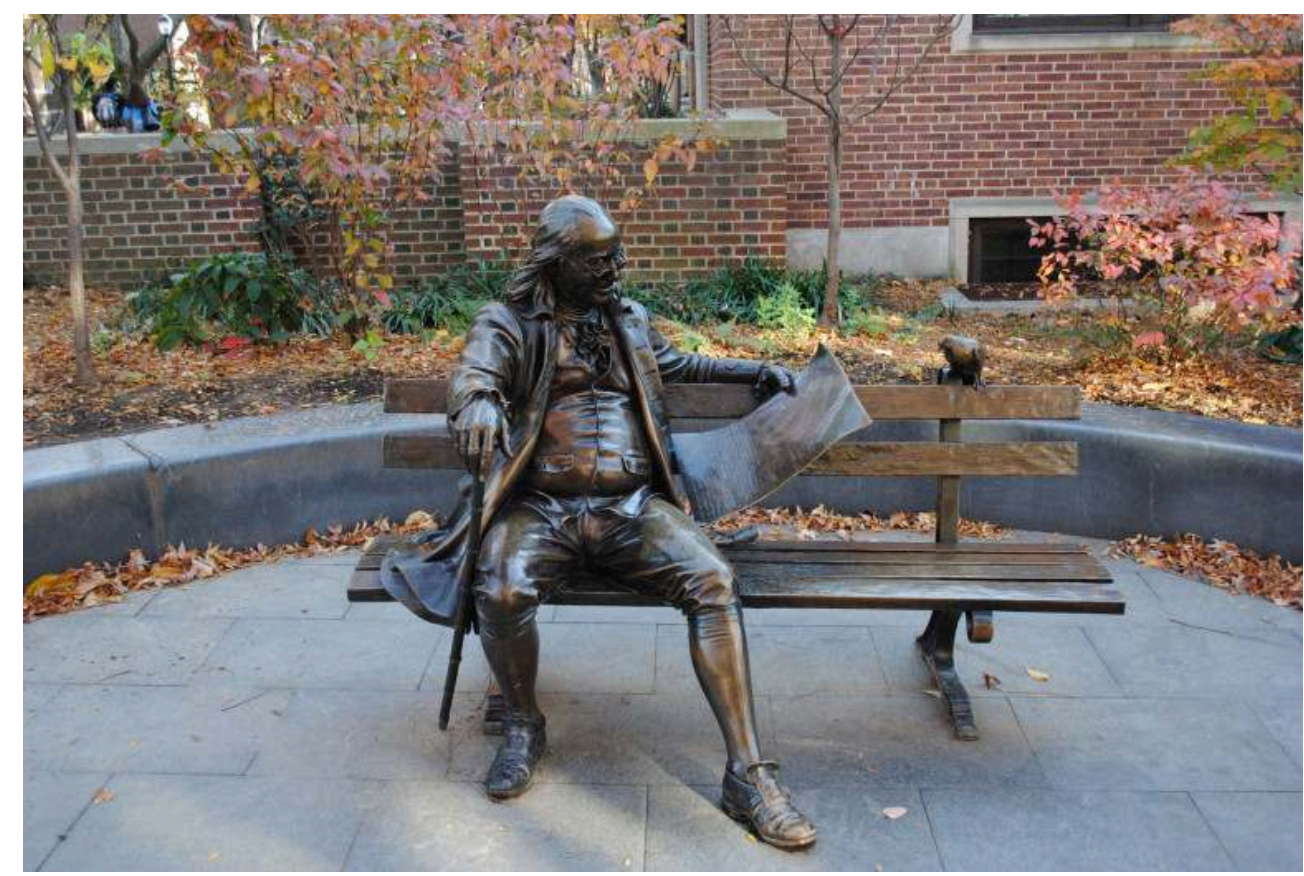

52 Fig. 6. George Lundeen. Ben on the Bench. 1987. University of Pennsylvania, Pennsylvania. The Penn Art Collection.

Representing the second half of the twentieth century's conception of art, this model of Franklin is depicted in a style that makes it accessible for the audience. More specifically, he is not located on a pedestal, in contrast to the nineteenth century models. Additionally, he is sitting on a bench like one of the residents of the city. He is modeled in his middle-ages while reading a newspaper page with a friendly look, so much different from the traditional stern faces of the sculptures of statesmen. He is given a friendly and inviting facial expression, as though he would get involved in a conversation with any townsfolk who sat next to him on the bench. This difference between those models looking down from the tops of pedestals to one closer to the audience, exhibits the change in society's attitude toward the historical public figures 
in relation to their views on contemporary politics. It should be also noted that the artist was commissioned to honor the $25^{\text {th }}$ reunion of the alumni of the University of Pennsylvania ("Ben on the Bench"). Obviously, similar to the statue of Young Benjamin Franklin by McKenzie, Lundeen's model is also expected to be an object of inspiration for the young generations as it was shaped as per the expectations of the youth.

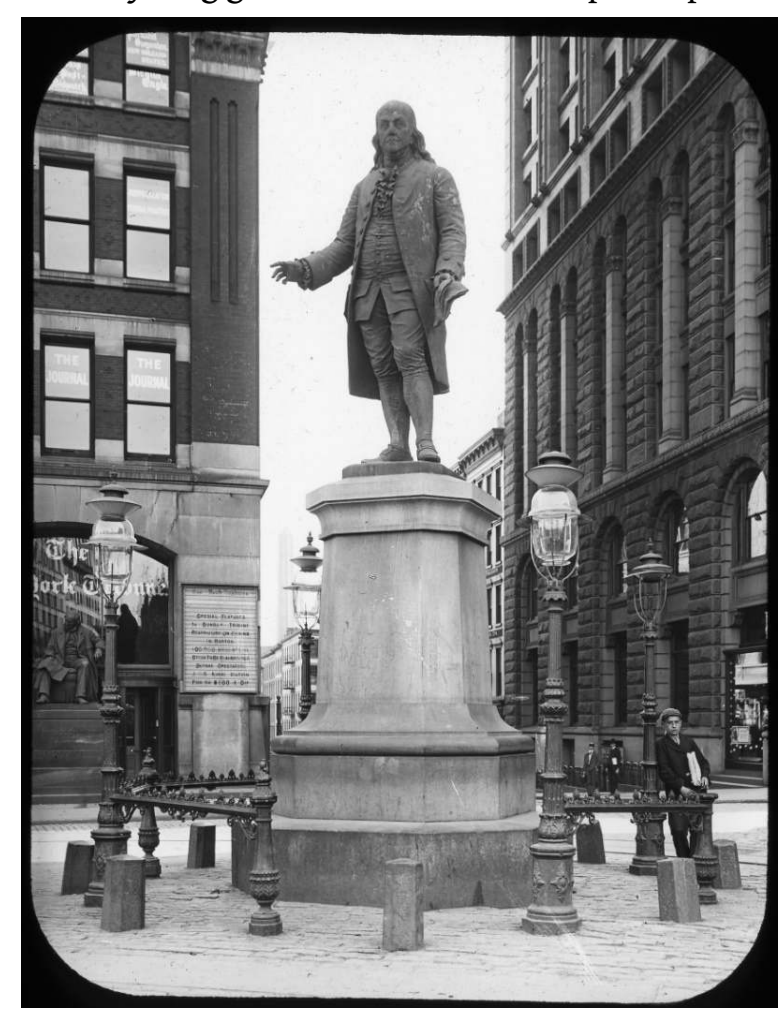

Fig. 7. Ernst Plassman. Benjamin Franklin Statue. 1856. New York States Archives, New York City. Digital Collections.

In this matter, Franklin's accessibility and inviting manner represent his eagerness to share information with public as an ideal democrat. Meanwhile, he is accompanied by a bird on the bench. This depiction can also be interpreted as he is telling something to the bird, which is a pigeon, used for carrying messages from one place to another in the past, hence an informant like Franklin, himself. Therefore, it can be argued that the pigeon symbolizes Franklin's efforts to inform public audience about social and political issues. All in all, Lundeen's Franklin constitutes an ideal model for a democratic leader.

In contrast to this egalitarian representation of Franklin in Lundeen's work, another model of Franklin, which highlights him as a printer and a writer, is the statue of him in Printing House Square, New York City (Fig. 7). These two different Franklins clearly display the change between the approaches of society after a century. Plassman's model was gifted to the Press of New York City, and Franklin was praised as an "eminent printer, statesman and philosopher" in the unveiling ceremony of the statue in 1872 ("The Franklin Statue in Printing House Square").

Compared to Lundeen's statue, Plassman's Franklin is depicted addressing an audience from the top of a pedestal. It should be remembered that Lundeen's work was made after the Civil Rights Movements in the 1950s and 1960s, whereas Plassman's work was made in the Antebellum Era, when depicting a public figure like Franklin as sitting on a 
bench like an ordinary member of society would have contrasted with the generally accepted norms of sculpture. The location of Plassman's statue in a public gathering area, rather than a university campus like the former's location, also corresponds to Franklin's depiction as a public figure on a pedestal in contrast to an ordinary campus resident, inviting his neighbors and colleagues to a conversation in Lundeen's depiction. Moreover, Franklin's serious appearance, again in contrast to the smiling and energetic model of Lundeen, displays how the emphasis moved from a wise political leader to a modest and egalitarian social figure in accordance with society's understandings of ideal political leaders over time.

\subsection{The Enlightened Scientist}

Benjamin Franklin was also recognized by his contributions in science as early as the year of 1753 , when he was awarded with the Copley Medal by the Royal Society (Morgan 71). Science was a perfect field for a man like Franklin. With its endless potential, he could chase the new frontiers of progress. His optimism let him imagine very complex and dangerous experiments, such as those involving electricity which were rather ground-breaking for his era. These experiments provided a way of keeping his overactive mind busy enough, so he invested his entire time for science, except for the times when his genius is needed for the public service, mainly as a diplomat during the revolution.

Agnes Yarnell's Benjamin Franklin with Kite, which opened to the public in 1965, reflected all of these features of Franklin as a scientist-or the characteristics that society attributed to him. In this model, Franklin is holding a kite, referring to his famous experiment in which he proved that thunder lights are electrical in 1752 (Fig. 8). As for his facial expressions, he has a hopeful, optimistic and prideful look on his face, referring to his aforementioned personal characteristics that enabled him to pursue his scientific exploits for years.

With his posture, holding the kite like a child, waiting for the right wind to play with his toy, and location of the statue next to a playground, Franklin stands as a role model for the future scientists and represents the ideal model of a man of science, from Yarnell's perspective, of course. It is true that Franklin and his compatriots imagined America to be a country where science could flourish without any limitations, and Cartesian way of thinking ushered the path before the country's scientific progress without any hindrance caused by the institutions like the Church and the State as had been the case in Europe for centuries. 


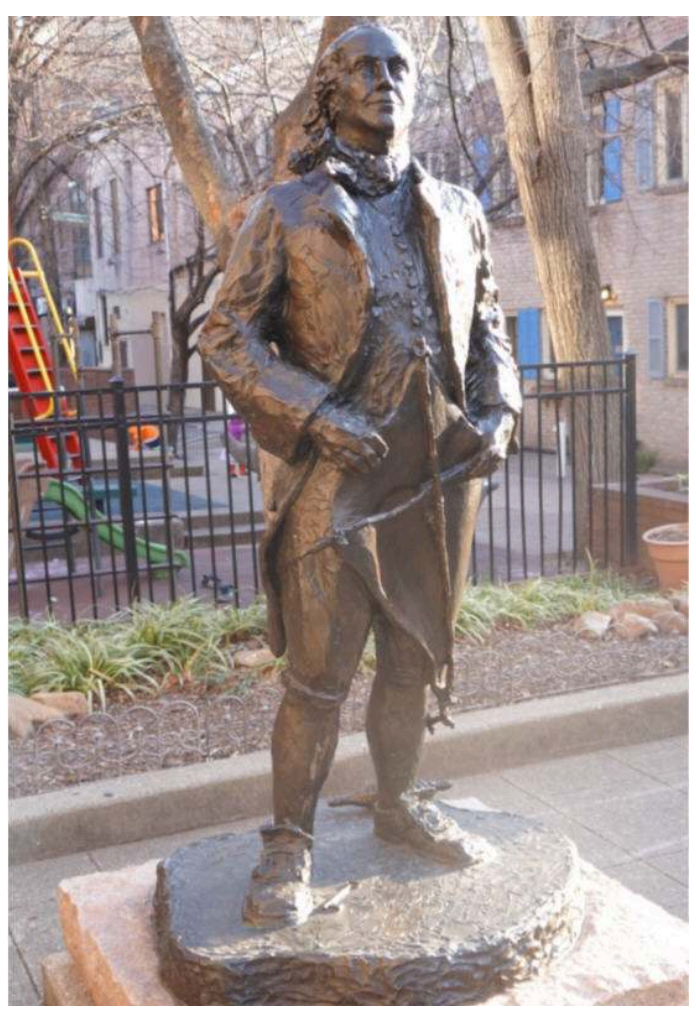

61 Fig. 8. Agnes Yarnall. Benjamin Franklin with Kite. 1965. Photographed by Christopher William Purdom. Philadelphia Public Art.

62 Furthermore, at the time when the statue was made, the United States was in the middle of the space race against the Soviets just four years before Apollo 11 space mission completed its task by landing an astronaut on the Moon in 1969. The space race was the scientific side of the competition between these superpowers as they were both trying to prove which one is better in this field to one another as well as the rest of the world. Of course, Franklin, acknowledged as the first American scientist, was one of the most significant reminders of the roots of scientific tradition and achievements of America. Therefore, Yarnell's highlighting Franklin's identity as a scientist is once again an example of how the contemporary era of an artifact of history shapes it.

\subsection{The Diplomat}

Nineteenth century diplomacy was shaped by the concept of the Balance of Powers after the Treaties of Paris in 1814-5 and particularly the Congress of Vienna of 1815, concluding the Napoleonic Wars. The dawn of the twentieth century came with the advocacy of Free Trade and Self-Determination, and peaked with the ill-fated Treaty of Versailles, yet both of these developments had their roots in the newly enlightened diplomats of the Age of Reason. Franklin was, once again, a pioneer of this new kind of man as he recognized the importance of deterrence, by the means of military strength, and did not deny the role of power in diplomacy, but he also believed that war was nothing but a means of diplomacy-almost half a century before Clausewitz wrote on War-as he argued that reason would lead humanity to recognize their ultimate common-interest, which is peace and a commonwealth of nations (Stourzh, 245-6). 
this recently made statue, James West depicts Benjamin Franklin and George Washington together as the former is bringing a masonic apron to the latter and inviting him to follow (Fig. 9). It is well-known that Franklin was involved in the masonic circles and other fraternities both in Philadelphia (Isaacson 106) and Paris, he used such connections to promote the cause of the American Revolution (Weisberger 168). Therefore, the statue can be interpreted as Franklin's invitation of Washington to the social organization that he established as a diplomat in France owing to his connections with the masonic orders and that led the path toward the FrenchAmerican alliance, which secured their victory in the Revolutionary War. In other words, Franklin shows the path to victory, passing through the achievements in diplomatic relations, to Washington.

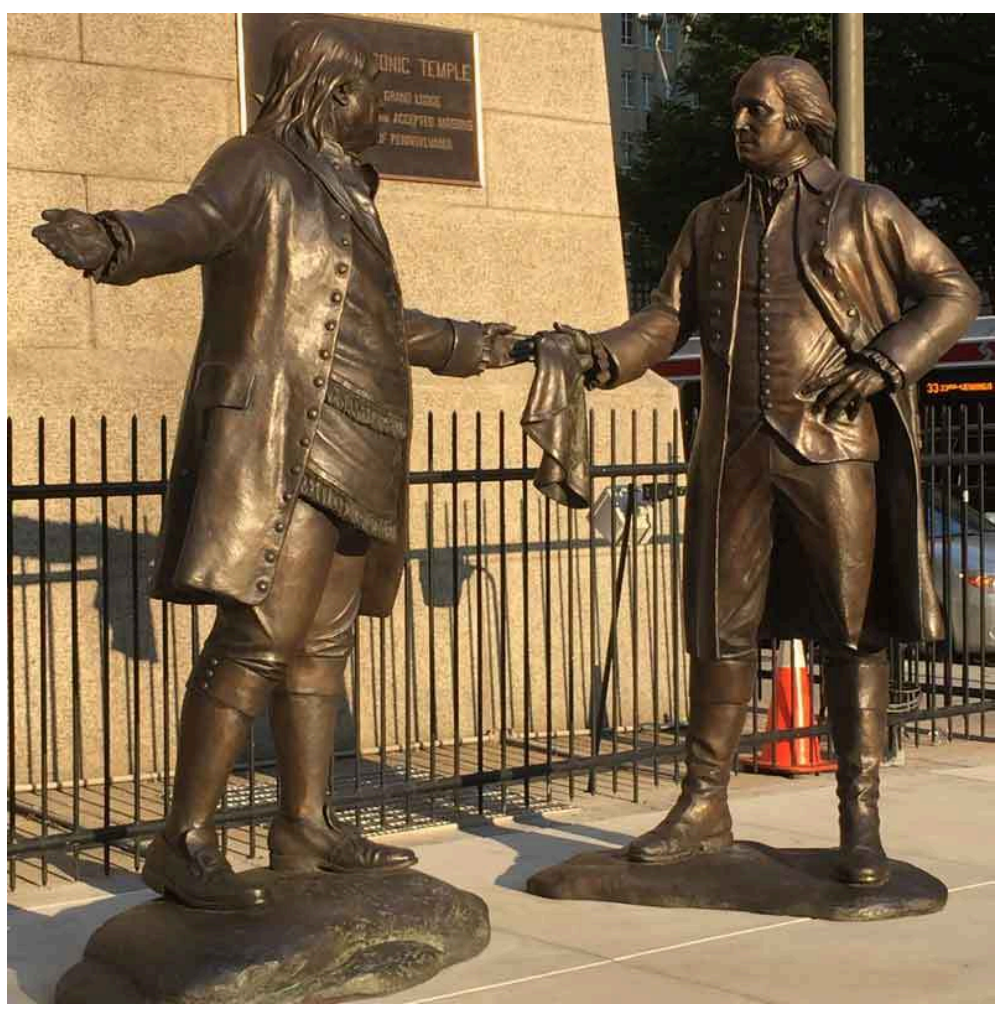

Fig. 9. James West. The Bond. 2017. Photographed by Christopher William Purdom. Philadelphia Public Art.

Hence, the name of this work of art, The Bond, refers to this connection between these fraternity organizations, which counted Washington, Lafayette, Voltaire, and of course Franklin as members. The masonic apron, given by Washington to Franklin in the depiction, represents the bond of fraternity between the Founding Fathers. In this regard, the concept of fraternite is materialized as one of the fundamentals of the sister revolutions of the French and Americans as a cultural concept of the countries. 


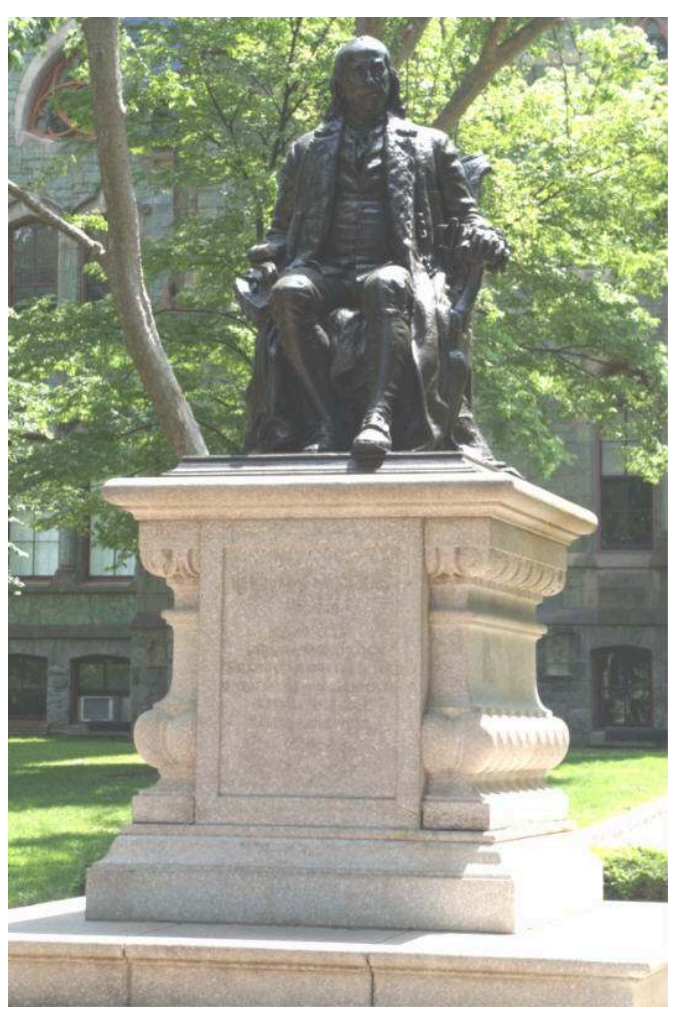

Fig. 10. John J. Boyle. Benjamin Franklin. 1899. Photographed by Christopher William Purdom. Philadelphia Public Art.

From the gender-specific perspective, The Bond is one of such works of art that sublimize brotherhood and homosocial bounds. Eighteenth century politics was the realm of men to prove their manhood, and the masonic lodges provided the physical settings for the reunion of men as they could exchange their opinions on arts, science, politics, and commerce while establishing new bonds.

Although the lodges of America did not declare a unified support to the Revolutionary War, some of the leading Freemasons, such as Paul Revere and Joseph Warren, served to the Independence Movement and supported the values of their lodges like freedom, egalitarianism, industriousness, civic-duty, and patriotism in the discourse of the movement (York 323-9). Eventually, the Freemasons, who were among the ranks of the Patriots, found a new opportunity to reinforce their bonds as well as actualize themselves in the defense of the values that they perceived as sublime.

After all, the Nine Sisters, a Paris-based masonic lodge, was one of the two centers of Franklin's activities to establish new contacts with the French elite and to strengthen the already-existing ones (Isaacson 355). All of these are reflected in another statue, again related to Franklin's endeavors in France to gain much needed support for the Revolutionary America against the British Empire. Sculpted by John Boyle and opened to public in 1899, this statue, a replica of which is located in Paris while the original is in Philadelphia, is a symbol of Franklin's heroic status in both countries and of the long-established relations between them. Depicting Franklin as sitting on a chair, it is positioned above a pedestal, on which the following quotation from Washington is vertically written: "Benjamin Franklin 1706-1790/ Venerated for Benevolence/Admired for Talents/ Esteemed for Patriotism/ Beloved for Philanthropy - Washington" (Fig. 10). 
71 Henceforth, Washington's words were originally written in his letter to Franklin on September 23, 1789 in order to convey the former's good wishes and compliments to the latter, who was suffering from age-related health problems (Washington). These words bring together most of the characteristics, attributed to Franklin by the creators of the statues, having been examined as the narrators of the artifacts of history in this study so far. Washington's words also reveal how history, memories and narratives are entangled in a monumental artifact in such a manner that it provides new layers of identity to its subject, namely Franklin in this case, and how such memories turn into identity models in the course of this process.

Regarding the identity model that is collectively created by these statues, it conveys a message to the audience about the international affairs of the United States. The country was founded in collaboration with its allies, and thanks to its unity, it could survive. Supported by the consolidated power of their country, diplomats like Franklin established bonds with the allies of the United States so as to go through the challenges that their country confronted since its foundation. These bonds of mutual respect and understanding have been the sources of American power in the foreign affairs, rather than crude military power. Considering the recent discussions regarding NATO, French-American relations, and the Trump administration's attitude toward its country's oldest ally, the first statue, particularly, becomes more meaningful, while the latter proves that these bonds between the United States and its allies had quite deep roots in the histories of these countries.

\subsection{The Founding Father}

The final statue of Benjamin Franklin to be considered is James Earle Fraser's model, erected in 1938 (Fig. 11). The Journal News reported the unveiling of the statue by President Franklin Delano Roosevelt with these words on Franklin, echoing those of Washington a century and a half later: "the great citizen, printer, scientist, educator, patriot and statesman" ("Franklin Statue to be Unveiled by President" 3). This model provides the last episode of Franklin's life as a founder and patriarch of American society. Although Fraser's depiction seems to be lack of any significant references to Franklin and of a socio-historical conception, the plainness of the depiction has also its own message. Simplicity and modesty were among the characteristic principles of Franklin, who did not wear wigs or any luxurious cloths, either, even though it was in fashion for the elite men of his era (Isaacson 327-8). Causing the birth of a new identity model, Franklin avoided extravagance and praised practicality as well as simplicity in manners, thought, and appearance. Therefore, Franklin defined the apparel of the Modern Man, along with the Modern Society. 


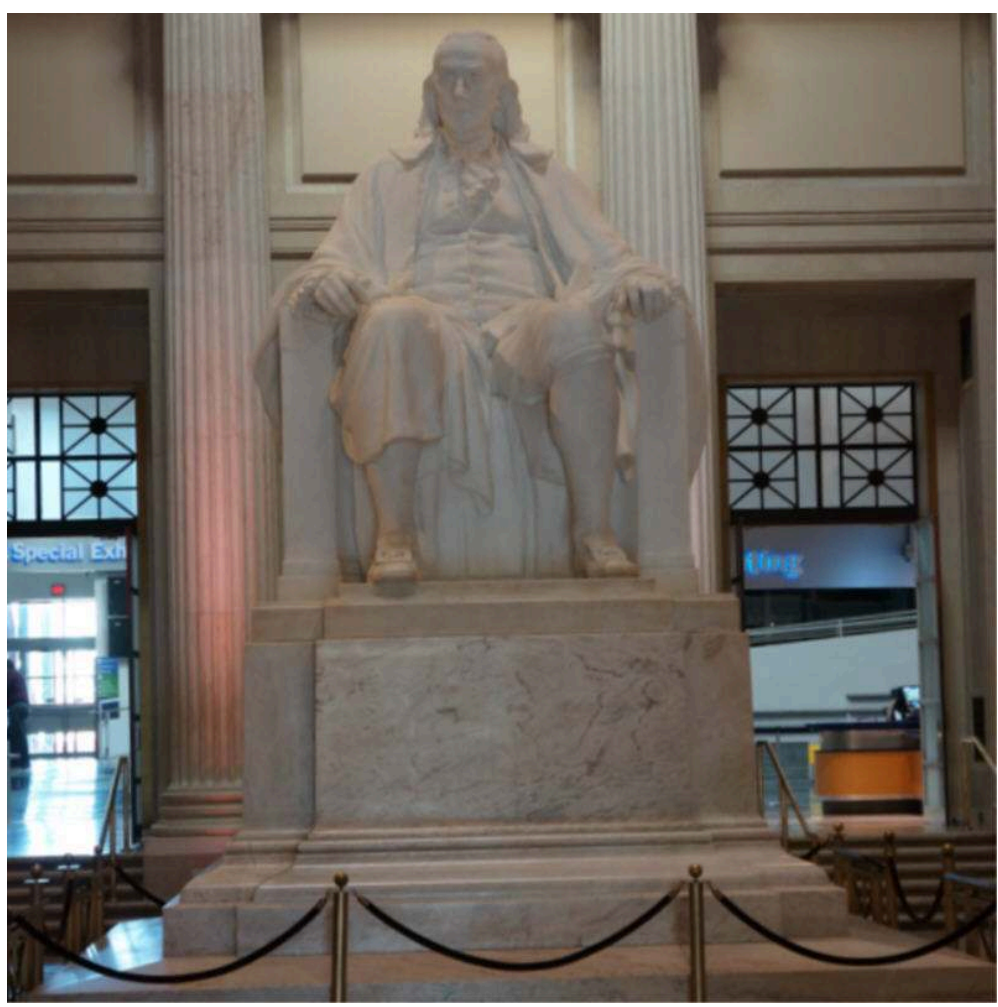

74 Fig. 11. James Earle Fraser. Benjamin Franklin. 1938. Photographed by Christopher William Purdom. Philadelphia Public Art.

Regarding the date of the statue's inauguration, it is obvious that the statue's messages of simplicity and frugality represent the promoted social behaviors of the New Deal government in order to decrease consumption and extravagance in the Great Depression years. It should be also remembered as it is frequently seen in other portraits of Franklin that he is associated with optimism and referred to be the embodiment of the success after hardworking as a Self-Made Man. In the year of 1938, one of the biggest concerns of American society was the loss of social mobility, which had been degrading for years since the Reconstruction Era. It was much more difficult or even impossible to climb up the socioeconomic ladder like Franklin had done.

Furthermore, the used-material and details of Franklin's cloths also indicate another aspect of this model. Apparently, he is clad in more clothes than normal, as though he were wearing a toga or a judge's robe, so the Romanesque details constitute a part of another Franklin statue, together with Lazzarini's, as the indicators of virtuousness and Republicanism. On the other hand, he is portrayed as sitting, yet his seat resembles to a throne more than an ordinary chair. Also, regarding the material of the statue, it is made of white marble, again another Romanesque detail.

When all of these details come together, it is clear that Franklin is intended to be seen as a patriarchal figure, a Founding Father of the United States. Hence, the statue still presents its subject in a formidable manner with all his impressiveness because he does not look tired despite the difficulties that the United States was facing, but rather he has a decisive look in his visage. In parallel with this, he is still on his throne-like chair as a patriarch, showing that Americans could still remember and pay respect to their patriarchs in spite of being in the middle of the biggest crisis in their history, yet neither his seat nor clothes are made of any precious or gilded metals, making its 
audience remember that Franklin, one of the richest members among the founders-if not the richest-was also one of the most humble ones in his appearance and demeanor.

Consequently, the simplicity of Franklin's look conveyed the message that he was quite different from the aristocrats of his own era as a new type of patriarch, who was as influential and cultivated as his counterparts, who inherited their social statues despite Franklin's humble beginnings, but Franklin was also more adaptable to the new era at the dawn of the Age of Industry with his exaltation of reason and freedom of expression. His material richness did not reflect on his appearance, but his intellectual depth and righteousness were represented by his commitment to civil-service and patriotism as well as his advocacy of liberty, equality and social solidarity under a democratic republic.

\section{Conclusion}

79 Memory is reproduced by the nature of remembering; thus, the individual needs to make sense of this fragmented source of history, and in this pursuit, he or she has to create narrations of the past. This process of reconstruction of the past is almost instinctive for human beings as they develop their identities by the means of this very same process. They reflect their subjectivities and memories on an artifact of history. Consequently, they believe to deliver the "truth" about their past, at the present moment. This sense of "truth" is not, however, a static model of the past; instead, it is a basis for defining and giving a meaning to the present as it can be comprehended only as the consequence of the past incidents, perceived to be interrelated with each other within the frame of causality. Therefore, meaning is created out of these artifacts and becomes the subject of the identity making process both for individuals as well as societies collectively.

Benjamin Franklin provides a perfect example for this interplay among memory, identity and history. Having lived an adventurous and productive life, Franklin had already become a public figure for his compatriots even before his death, and he began to be the favorite subject of their mythologies of an American hero. Subsequently, his story has not ended with his demise, rather he became the mold of the many faces of American society in the process of America's remaking of its identity in parallel with the changing world in different eras. The narrators, mainly artists and historians, remade new identities, such as the Self-Made Man, Heroic Artisan, Journalist, Scientist, Diplomat, and Founding Father, in the model of Franklin to find an answer to the deepest ontological question of mankind, "who are we?," at various moments in their history, ranging from the Early Republican Era's self-identification efforts, to the emphasis on unity in the Antebellum Era, to the exaltation of freedom after the war, to the redefinition of their country as a global actor at the time of the Great War, to the years of economic austerity in the Great Depression, and to the search for a more egalitarian democracy and society during the Civil-Rights Movements of the Cold War years.

81 Franklin's own characteristic of being the master of numerous crafts and arts helped this purpose, and the myth of Franklin was, then, born from the fragments of people's memory of him. America projected itself on its dear Father Franklin, and the American 
identity has been reproduced over the course of this still ongoing process. Franklin became America and America became Franklin.

\section{BIBLIOGRAPHY}

Apfelbaum, Erika. "Halbwachs and the Social Properties of Memory." Memory. Ed. Susannah Radstone, and Bill Schwarz. New York: Fordham University Press, 2010. 77-92. Print.

Beck, James M. The Youthful Franklin. Philadelphia: Franklin Printing Company, 1914. Print.

"Benjamin Franklin, Craftsman." Association for Public Art. Web. https://

www.associationforpublicart.org/artwork/benjamin-franklin-craftsman-or-young- benfranklin/. Accessed 1 January 2019.

"Benjamin Franklin (on a bench)." Association for Public Art. Web. https:// www.associationforpublicart.org/artwork/benjamin-franklin-on-a-bench/. Accessed 1 January 2019.

Benjamin Franklin Statue. 1856. New York States Archives, New York City. Digital Collections. Web. http://digitalcollections.archives.nysed.gov/index.php/Detail/object/Show/object_id/225. Accessed 30 December 2018.

Ben the Phan. 1993. University of Pennsylvania. Artstor Library. Web. artstor.org/asset/ SS37618_37618_40217755. Accessed 29 December 2018.

Boyle, John J. Benjamin Franklin. 1899. Photographed by Christopher William Purdom. Philadelphia Public Art. Web. http://philart.net/art/Benjamin_Franklin/20.html. Accessed 22 December 2018.

Brown, Joseph. Benjamin Franklin, Craftsman. 1981. Photographed by Christopher William Purdom. Philadelphia Public Art. Web. http://philart.net/art/Benjamin_Franklin_Craftsman/36.html. Accessed 21 December 2018.

Crane, W. Verner. Benjamin Franklin and a Rising People. Boston: Little, Brown and Company, 1954. Print.

Craven, Wayne. "The Origins of Sculpture in America: Philadelphia, 1785-1830." The American Art Journal 9.2 (1977). 4-33. Print.

Descartes, René. “Optics.” The Visual Culture Reader. Ed. Nicholas Mirzoeff. London and New York: Routledge, 2002: 60-5. Print.

Fischer, David Hackett. Liberty and Freedom. Oxford: Oxford University Press, 2005. Print.

"Franklin Statue to be Unveiled by President." The Journal News [Nyack, N. Y.], 28 Jan. 1938: 3. Print.

Fraser, James Earle. Benjamin Franklin. 1938. Photographed by Christopher William Purdom. Philadelphia Public Art. Web. http://philart.net/art/Benjamin_Franklin_National_Memorial/ 38.html. Accessed 24 December 2018.

Fryd, Vivien Green. “Hiram Power's 'America': ‘Triumphant as Liberty in Unity.” The American Art Journal 18.2 (1986): 54-75. Print. 
Foucault, Michel. The Archeology of Knowledge and The Discourse on Language. Trans. A.M. Sheridan Smith. New York: Vintage, 1982. Print.

Greene, Mark. A. “The Messy Business of Remembering: History, Memory, and Archives.” Archival Issues 28.2 (2003-2004): 95-103. Print.

Isaacson, Walter. Benjamin Franklin: An American Life. New York: Simon and Schuster, 2004. Print.

Kaldellis, Anthony. The Byzantine Republic: People and Power in New Rome. Cambridge, Mass.: Harvard University Press, 2015. Print.

Kennedy, Roger. "Memory and the Unconscious." Memory. Ed. Susannah Radstone and Bill Schwarz. New York: Fordham University Press, 2010. 179-97. Print.

Kimmel, Michael. Manhood in America: A Cultural History. Oxford: Oxford University Press, 2011. Print.

Lazzarini, Francesco. Benjamin Franklin. 1791. Photographed by Christopher William Purdom. Philadelphia Public Art. Web. http://philart.net/art/Benjamin_Franklin/21.html. Accessed 23 December 2018.

Lundeen, George. Ben on the Bench. 1987. University of Pennsylvania. The Penn Art Collection. Web. http://artcollection.upenn.edu/collection/art/?o=57-benjamin-franklin. Accessed 23 December 2018.

Martin, C.B., and Max Deutscher. “Remembering.” The Philosophical Review 75.2 (1966): 161-96. Print.

Madison, James. The Writings of James Madison, vol. 4. Edited by Gaillard Hunt. Online Library of Liberty. Web. http://oll.libertyfund.org/titles/madison-the-writings-vol-4-1787? q=james+madison\#lf1356-g04_head_004. Accessed 23 December 2018.

McKenzie, R. Trait. The Young Franklin. 1914. University of Pennsylvania. University Archives \& Records Center. Web. https://archives.upenn.edu/exhibits/penn-history/campus-art/mckenzieyoung-franklin. Accessed 21 December 2018.

Meriwether, Jeffrey Lee, and Laura Mattoon D’Amore. “Introduction.” We Are What We Remember. Ed. Jeffrey Lee Meriwether and Laura Mattoon D’Amore. Newcastle-upon-Tyne: Cambridge Scholars Publishing, 2013. xvi-xx. Print.

Morgan, Edmund S. Benjamin Franklin. New Haven: Yale University Press, 2002. Print.

Mulford, Carla. "Figuring Benjamin Franklin in America Cultural Memory." The New England Quarterly 72.3 (1999): 415-43. Print.

Powers, Hiram. Benjamin Franklin. 1920. Library of Congress Prints and Photographs Division, Washington, D.C. Library of Congress. Web. https://www.loc.gov/item/thc1995012085/PP/. Accessed 23 December 2018.

Stourzh, Gerald. Benjamin Franklin and American Foreign Policy. Chicago: The University of Chicago Press, 1954. Print.

Sutton, John, Celia B. Harris, and Amanda J. Barnier. "Memory and Cognition." Memory. Ed. Susannah Radstone, and Bill Schwarz. New York: Fordham University Press, 2010. 209-26. Print.

“The Franklin Statue in Printing House Square." Scientific American. 27 January 1872. Print.

“To George Washington from Unknown Author, 15 July 1784." The U.S. Archives Online. Web. https://founders.archives.gov/?q=washington\%2C\%20classics\&s=1111311111\&sa=\&r=8 \&sr=. Accessed 23 December 2018. 
Washington, George. "From George Washington to Benjamin Franklin, 23 September 1789." National Archives. Founders Online. Web. http://founders.archives.gov/documents/Washington/ 05-04-02-0045. Accessed 23 December 2018.

Weisberger, R. William. "Benjamin Franklin: A Masonic Enlightener in Paris.” A Journal of MidAtlantic Studies 53.3 (1986): 165-80. Print.

West, James. The Bond. 2017. Photographed by Christopher William Purdom. Philadelphia Public Art. Web. http://philart.net/art/The_Bond/1048.html. Accessed 23 December 2018.

York, Neil L. "Freemasons and the American Revolution." The Historian 55.2 (1993): 315-330. Print.

"Young Franklin Statue." Art on Campus. University Archives and Records Center, University of Pennsylvania. Web. https://archives.upenn.edu/exhibits/penn-history/campus-art/mckenzieyoung-franklin. Accessed 30 December 2018.

Yarnell, Agnes. Benjamin Franklin with Kite. 1965. Photographed by Christopher William Purdom. Philadelphia Public Art. Web. http://philart.net/art/Benjamin_Franklin_and_His_Kite/35.html. Accessed 23 December 2018.

\section{ABSTRACTS}

History and memory are always in interaction as history is the craft of composing fragments of memory into an understandable narrative, so it serves as a medium of transferring memories between individuals, who thus achieve a form of self-definition. However, due to the specific nature of memory as well as the discipline of history's own methods of reconstructing memory, the subjects of history are recreated over and over again in each artifact of history. The statues of Benjamin Franklin, honoring one of the most popularly acknowledged individuals in American history and social memory, perfectly exemplify the interrelation between history and memory. Benjamin Franklin, art history, social-cultural history, sculpture, remembering, memory, identity, narration

\section{AUTHOR}

\section{MERT DENIZ}

Mert Deniz holds an MA in History from Bilkent University with a thesis on the foreign relations between the Bolsheviks and the American Progressives before and during the Great War. He is currently a Ph.D. student in the Department of American Culture and Literature at Hacettepe University. His research interests include American social, political and diplomatic history and Anglo-American Literature with an emphasis on identity, culture and international relations. 